\title{
PERSISTENSI LABA PERUSAHAAN MANUFAKTUR SEKTOR INDUSTRI BARANG KONSUMSI: BESERTA FAKTORNYA
}

\author{
Oleh: Dirvi Surya Abbas ${ }^{1}$, Imam Hidayat ${ }^{2}$ \\ abbas.dirvi@gmail.com ${ }^{1}$, Imam_accounting@yahoo.com ${ }^{2}$ \\ (Program Studi Akuntasi, Fakultas Ekonomi dan Bisnis Universitas \\ Muhammadiyah Tangerang)
}

\begin{abstract}
Abstrak-Tujuan dari penelitian ini untuk mengetahui secara empiris pengaruh Arus Kas Operasi, Tingkat Hutang, Ukuran Perusahaan terhadap Persistensi Laba. Populasi penelitian ini meliputi seluruh perusahaan manufaktur sektor industri barang konsumsi yang terdaftar di Indonesia tahun 2013-2017. Teknik pengambilan sampel menggunakan purposive sampling dengan menggunakan analisis regresi data panel dalam memgetahui hubungan antara variabel independen dengan variabel dependen. Jenis metode penelitian ini adalah berjenis Kausal-Komparatif. Berdasarkan kriteria yang telah ditetapkan diperoleh 14 perusahaan. Jenis data yang digunakan adalah data sekunder yang diperoleh dari situs Bursa Efek Indonesia. Metode analisis yang digunakan adalah analisis regresi data panel dengan berbantuan Eviews 9.0. Hasil penelitian menunjukkan bahwa Arus Kas Operasi dan Tingkat Hutang berpengaruh positif terhadap Persistensi Laba, sedangkan ukuran perusahaan tidak berpengaruh terhadap Persistensi Laba.
\end{abstract}

Kata Kunci: Persistensi Laba, Arus Kas Operasi, Tingkat Hutang, Ukuran Perusahaan

\begin{abstract}
The purpose of this study is to empirically determine the effect of Operating Cash Flow, Debt Level, Company Size on Earnings Persistence. The population of this study includes all manufacturing companies in the consumer goods industry sector registered in Indonesia in 2013-2017. The sampling technique used purposive sampling using panel data regression analysis to determine the relationship between the independent variable and the dependent variable. This type of research method is the Causal-Comparative type. Based on the predetermined criteria, 14 companies were obtained. The type of data used is secondary data obtained from the Indonesia Stock Exchange website. The analysis method used is panel data regression analysis with the help of Eviews 9.0. The results showed that operating cash flow and debt level had a positive effect on earnings persistence, while firm size had no effect on earnings persistence.
\end{abstract}

Keywords: Earnings Persistence, Operating Cash Flow, Debt Level, Firm Size 


\section{PENDAHULUAN}

Pada kasus PT. Indofarma Tbk pada tahun 2004 melakukan penyajian laba dengan cara menaikkan overstated laba bersih senilai Rp. 28,780 milyar, sehingga dampak dari penilaian persediaan barang dalam proses yang lebih tinggi dari yang seharusnya mengakibatkan harga pokok penjualan tahun tersebut overstated. Target yang ingin dicapai dalam praktik ini adalah menaikkan laba (Barita, 2016).

Masih dalam sub sektor farmasi, skandal manipulasi laba terjadi pada perusahaan farmasi terbesar di Indonesia yaitu PT. Kimia Farma Tbk. Tahun 2002, PT. Kimia Farma Tbk terbukti melakukan pengelembungan keuntungan. Hal tersebut diketahui setelah dilakukannya audit ulang atas laporan keuangan tanggal 31 Desember 2001 dimana dilaporkan adanya laba bersih sekitar Rp 132 milyar, namun ketika dilakukan audit ulang tenyata laba bersih perusahaan hanya sebesar Rp 99,56 milyar. Dimana lebih rendah Rp 32,6 milyar atau $24,7 \%$ dari laba yang dilaporkan.

Perbedaan saldo laba dikarenakan adanya 2 kesalahan, pertama kesalahan penyajian dasar berkaitan dengan persediaan yaitu harga persediaan di mark-up dan dijadikan dasar penilaian persediaan, yang kedua kesalahan dalam penyajian yang berkaitan dengan penjualan yaitu dengan dilakukannya pencatatan ganda atas penjualan (http://kompasiana.com).

Kasus yang terjadi seperti pada penjelasan yang diatas memberikan informasi bahwa perusahaan tidak menyajikan laba yang sebenarnya pada laporan keuangan tentu laba perusahaan juga diragukan kualitasnya. Semakin kecil manipulasi laba akan menyebabkan laba menjadi semakin berkualitas. Laba yang berkualitas adalah laba yang dapat mencerminkan kelanjutan laba (Septavita, 2016).

Laba merupakan hasil dari kinerja suatu perusahaan. Laba yang berkualitas mampu mencerminkan laba dimasa yang akan mendatang pada perusahaan tersebut. Untuk dapat mengetahui informasi tersebut didapat dari media komunikasi yaitu laporan keuangan, dimana laporan keuangan diperuntukan kepada pihak-pihak yang berkepentingan terhadap suatu perusahaan.

Kelanjutan laba disebut juga persistensi laba, dimana persistensi laba merupakan suatu ukuran yang menjelaskan kemampuan perusahaan untuk mempertahankan jumlah laba yang diperoleh saat ini sampai satu periode masa depan (Ariyani dan Wulandari, 2016). Persistensi laba seringkali digunakan sebagai pertimbangan kualitas laba. Laba yang bermanfaat bagi investor adalah laba yang berkualitas (Asma, 2013). Maka laba yang persisten lebih bermanfaat dalam pengambilan 
keputusan daripada laba yang tidak persisten.

Konsep mengenai persistensi laba dapat dijelaskan dengan menggunakan pendekatan teori keagenan (agency theory). Agency theory merupakan menggambarkan kerangka kerja untuk menganalisa pelaporan keuangan antara manager dan pemilik perusahaan. Laporan keuangan dijadikan dasar pengambilan keputusan ekonomis berbagai pihak yang berkepentingan atas perusahaan atau suatu entitas (stakeholders) (Linawati, 2016).

Para investor dan kreditor ataupun pengguna laporan keuangan lainnya menggunakan laba sebagai salah satu bagian dari laporan keuangan untuk mengevaluasi kinerja dan aktivitas ekonomi perusahaan, tentunya para pengguna laporan keuangan mengharapkan laba yang dihasilkan oleh perusahaan merupakan laba yang berkualitas tinggi. Dikarenakan hal tersebut digunakan sebagai dasar untuk pengambilan keputusan.

Laba yang diperoleh bukan hanya dilihat dari besar atau kecilnya tetapi kemampuan perusahaan untuk mempertahankan laba tersebut juga menjadi perhatian bagi para penggunanya, hal tersebut lebih dikenal dengan persistensi laba (Linawati, 2016). Persistensi laba diharapkan dapat menunjukan prediksi laba dimasa depan suatu perusahaan. Maka laba yang persistensi cenderung stabil disetiap periode (Septavita, 2016).

Berdasarkan motivasi dan fenomena diatas yang menggambarkan persaingan yang ketat antar perusahaan manufaktur dalam memperoleh laba yang berkelanjutan, diiringi dengan adanya kasus yang dialami oleh PT. Indofarma Tbk (INAF) dan PT. Kimia Farma Tbk (KAEF). Serta didukung dengan penelitianpenelitian terdahulu tentang arus kas operasi, tingkat hutang, dan ukuran perusahaan terhadap persistensi laba yang menunjukan hasil yang kontradiktif. Selain itu penulis juga tertarik untuk meneliti perusahaan manufaktur sektor industri barang konsumsi dikarenakan barang konsumsi tidak pernah terlepas dari kebutuhan primer manusia. Sehingga bagi perusahaan yang bergerak pada sektor industri barang konsumsi akan sangat dibutuhkan keberadaannya.

\section{METODE PENELITIAN}

Pendekatan dalam metode penelitian ini dengan berbasis metode deskriptif. Basis metode deskriptif ialah basis penelitian yang diterapkan dalam menghimpun data sehingga menemukan jawaban atas dugaan yang digunakan dalam penelitian ini, atau agar menemukan konfirmasi jawaban didalam penelitian ini mengenai keputusan penelitian terakhir dari subyek penelitian dengan komplit dan akurat atas suatu situasi. 
Adapun populasi dalam penelitian ini menggunakan perusahaan manufaktur sub sektor makanan dan minuman yakni sebanyak 42 perusahaan dengan tahun pengamatan 2013-2017 terdaftar di BEI. Setelah dilakukan seleksi dari kriteria yang ditetapkan dengan metode purposive sampling didapatkan $14 \quad$ Perusahaan manufaktur sub sektor makanan dan minuman yang layak digunakan dalam penelitian ini. Hal tersebut didasari terdapat 7 Perusahaan yang tidak yang tidak mempublikasikan laporan keuangan secara berturutturut, lalu, terdapat 12 Perusahaan yang mengalami rugi dan didapati 9 Perusahaan yang mengalami kerugian dalam aktifitas operasional selama tahun pengamatan. Sehingga didapatkan sampel penelitian sebanyak 70 sampel penelitian dari 14 populasi yang digunakan dikali dengan dengan 5 tahun pengamatan.

Analisis data yang digunakan meliputi analisis statistik deskriptif, uji model estimasi data panel, uji hipotesis dan uji model regresi data panel. Semua pengujian pada penelitian ini menggunakan software Eviews versi 9.0.

\section{Persistensi Laba (Y)}

Perhitungan persistensi laba menggunakan skala data rasio diukur dengan cara membagi laba sebelum pajak tahun depan dibagi dengan rata-rata total asset. Persistensi laba diukur sebagai berikut:
Persistensi Laba $=$ Laba sebelum pajak $\mathrm{t}+1$ Rata-Rata Total Aset

\section{Arus Kas Operasi $\left(\mathbf{X}_{1}\right)$}

Arus kas operasi dapat dilihat pada laporan arus kas yang terdapat dalam laporan keuangan perusahaan. Sehingga arus kas operasi diukur sebagai berikut:

Arus Kas Operasi = Jumlah Arus Kas Operasi

\section{Tingkat Hutang $\left(\mathbf{X}_{2}\right)$}

Tingkat hutang yang tinggi menunjukkan peningkatan dari resiko kepada kreditor berupa ketidakmampuan perusahaan membayar hutang (Hayati, 2014). Tingkat hutang diukur sebagai berikut:

Tingkat Hutang $=\frac{\text { Total Hutang }}{\text { Total Aset }}$

\section{Ukuran Perusahaan $\left(\mathbf{X}_{\mathbf{3}}\right)$}

Ukuran perusahaan Skala yang menunjukan besar / kecilnya perusahaan (Nurochman, 2015). Ukuran perusahaan diukur sebagai berikut:

Ukuran Perusahaan $=$ Ln $($ Total Aset) 
Tabel 1. Statistik Deskriptif

\begin{tabular}{|l|c|c|c|c|}
\hline & PRST & AKO & TH & UP \\
\hline Mean & 0.155500 & $1.87 \mathrm{E}+12$ & 0.400786 & 1.270 .987 \\
Median & 0.121000 & $3.93 \mathrm{E}+11$ & 0.398000 & 1.258 .800 \\
Maximum & 0.634000 & $9.27 \mathrm{E}+12$ & 0.726000 & 1.396 .300 \\
Minimum & 0.042000 & $1.64 \mathrm{E}+09$ & 0.164000 & 1.122 .400 \\
Std. Dev. & 0.124239 & $2.60 \mathrm{E}+12$ & 0.147972 & 0.696832 \\
\hline
\end{tabular}

Sumber: Eviews 9, 2020

\section{HASIL DAN PEMBAHASAN}

Dari tabel 1 menunjukan bahwa variabel dependen, yaitu persistensi laba memiliki minimum sebesar 0.042000 yang diperoleh dari PT. Nippon Indosari Corporindo Tbk pada tahun 2017 sedangkan untuk nilai maksimumnya sebesar 0.634000 diperoleh dari PT. Unilever Indonesia Tbk pada tahun 2017. Memiliki nilai rata-rata sebesar 0.155500 dan standar deviasi sebesar 0.124239. Hal ini menunnjukan bahwa persistensi laba oleh perusahaan masih cukup rendah, dapat dilihat dari nilai rata-rata yang tidak mencapai $50 \%$.

Dari tabel 1 menunjukan bahwa variabel independen, yaitu arus kas operasi memiliki nilai minimum sebesar 1.641.040.298 yang diperoleh dari PT Sekar Laut Tbk tahun 2016 sedangkan untuk nilai maksimumnya 9.269.318.000.000 yang diperoleh dari PT. Indofood Sukses Makmur Tbk tahun 2014. Memiliki nilai ratarata sebesar $1.87 \mathrm{E}+12$ dan standar deviasi sebesar $2.6 \mathrm{E}+12$.
Dari tabel 1 menunjukan bahwa variabel independen kedua, yaitu tingkat hutang memiliki nilai minimum sebesar 0.164000 yang diperoleh dari PT. Darya Varia Laboratoria Tbk tahun 2017 sedangkan untuk nilai maksimumnya 1.091.000 yang diperoleh dari PT Unilever Indonesia Tbk tahun 2017. Memiliki nilai rata-rata sebesar 0.400789 dan standar deviasi sebesar 0.147972 .

Dari tabel 1 menunjukan bahwa variabel independen ketiga, yaitu ukuran perusahaan memiliki nilai minimum sebesar 1.122 .400 yang diperoleh dari PT. Sekar Laut Tbk tahun 2014 sedangkan untuk nilai maksimumnya 1.396 .300 yang diperoleh dari PT Indofood Sukses Makmur Tbk tahun 2015. Memiliki nilai rata-rata sebesar 1.270.987 dan standar deviasi sebesar 0.696832 .

Kesimpulan Model Regresi Data Panel Yang Digunakan 
Tabel 2. Kesimpulan Model Regresi Data Panel

\begin{tabular}{clll} 
No. & \multicolumn{1}{c}{ Metode } & Pengujian & Hasil \\
\hline 1 Uji Chow & CEM vs FEM & FEM \\
2 Uji Hausman & REM vs FEM & REM \\
3 Uji Lagrange Multiplier & CEM vs REM & REM \\
Sumber: Data diolah, 2020 & & & \\
asarkan hasil ke tiga & persamaan Regresi Data Panel \\
yang telah dilakukan, & adalah model Random Effect Model \\
at disimpulkan bahwa & (REM).
\end{tabular}

Model

Regresi Data Panel yang akan digunakan dalam Uji Hipotesis dan

\section{Tabel 3. Random Effect Model (REM)}

Dependent Variable: PRST

Method: Panel EGLS (Cross-section random effects)

Periods included: 5

Cross-sections included: 14

Total panel (balanced) observations: 70

Swamy and Arora estimator of component variances

\begin{tabular}{|c|c|c|c|c|}
\hline Variable & Coefficient & Std. Error & $\mathrm{t}$-Statistic & Prob. \\
\hline $\begin{array}{c}\text { C } \\
\text { AKO } \\
\text { TH } \\
\text { UP }\end{array}$ & $\begin{array}{r}0.450942 \\
1.00 \mathrm{E}-14 \\
0.203172 \\
-0.031130\end{array}$ & $\begin{array}{l}0.372114 \\
4.64 \mathrm{E}-15 \\
0.092261 \\
0.029266\end{array}$ & $\begin{array}{r}1.211837 \\
2.162623 \\
2.202151 \\
-1.063721\end{array}$ & $\begin{array}{l}0.2299 \\
0.0342 \\
0.0312 \\
0.2913\end{array}$ \\
\hline $\begin{array}{l}\text { Cross-section random } \\
\text { Idiosyncratic random }\end{array}$ & Effects Spe & tistics & $\begin{array}{c}\text { S.D. } \\
0.110577 \\
0.036494\end{array}$ & $\begin{array}{c}\text { Rho } \\
0.9018 \\
0.0982\end{array}$ \\
\hline $\begin{array}{l}\text { R-squared } \\
\text { Adjusted R- } \\
\text { squared } \\
\text { S.E. of regression } \\
\text { F-statistic } \\
\text { Prob(F-statistic) }\end{array}$ & $\begin{array}{l}0.078670 \\
0.036946 \\
2.963922 \\
0.038363\end{array}$ & $\begin{array}{l}\text { S.D. depend } \\
\text { Sum square } \\
\text { Durbin-Wat }\end{array}$ & $\begin{array}{l}\text { nt var } \\
\text { resid } \\
\text { on stat }\end{array}$ & $\begin{array}{l}0.038491 \\
0.090092 \\
1.457361\end{array}$ \\
\hline \multicolumn{5}{|c|}{ Unweighted Statistics } \\
\hline $\begin{array}{l}\text { R-squared } \\
\text { Sum squared resid }\end{array}$ & $\begin{array}{l}0.149050 \\
0.906289\end{array}$ & $\begin{array}{l}\text { Mean depen } \\
\text { Durbin-Wat }\end{array}$ & $\begin{array}{l}\text { ent var } \\
\text { on stat }\end{array}$ & $\begin{array}{l}0.155500 \\
0.144873\end{array}$ \\
\hline
\end{tabular}

Sumber: Data diolah, 2020 
Tabel 4. Hasil Rangkuman Hipotesis Penelitian

\begin{tabular}{|c|c|c|c|}
\hline No & Hipotesis & Signifikansi & Hasil \\
\hline 1. & $\mathrm{H}_{1}$ : Arus Kas Operasi berpengaruh positif & \multirow{6}{*}{$\begin{array}{l}\text { t-statistic } 2,162623 \\
\text { Prob. } 0.0342 \\
\text { t-statistic } 2,202151 \\
\text { Prob. } 0.0312 \\
\text { t-statistic }-1,063721 \\
\text { Prob. } 0.2913\end{array}$} & Diterima \\
\hline & dan signifikan Terhadap Persistensi Laba & & \\
\hline 2. & $\mathrm{H}_{2}$ : Tingkat Hutang berpengaruh positif & & Diterima \\
\hline & & & \\
\hline 3. & $\mathrm{H}_{3}:$ Ukuran Perusahaan tidak & & Ditolak \\
\hline & $\begin{array}{l}\text { berpengaruh negatif dan tidak Signifikan } \\
\text { Terhadap Persistensi Laba }\end{array}$ & & \\
\hline
\end{tabular}

Sumber: Rangkuman data diolah, 2020

\section{Pengaruh Arus Kas Operasi terhadap Persistensi Laba}

Variabel Arus Kas Operasi menunjukan koefisien sebesar 1,00E14 dengan nilai signifikansi sebesar 0,0342 . Karena tingkat signifikansi lebih kecil dari $\alpha=5 \%(0,0342<$ 0,050) maka hipotesis pertama $\mathrm{H} 1$ diterima, yang artinya bahwa arus kas operasi berpengaruh positif terhadap persistensi laba. Hasil penelitian ini sejalan dengan Hasil penelitian yang dilakukan oleh Dewi dan Putri (2015) dan Permata Sari (2018), yang mana arus kas operasi berpengaruh positif terhadap persistensi laba.

Pada dasarnya arus kas operasi bersumber dari kegiatan utama operasional suatu perusahaan. Dimana kas yang masuk dari operasional lebih banyak dari pengeluaran yang dilakukan perusahaan. Sehingga perusahaan memiliki kas yang akan digunakan kembali untuk melakukan operasional perusahaan. Dan hal ini menunjukan apabila operasional perusahaan baik maka akan menghasilkan laba yang baik pula.
Sehingga arus kas yang besar akan mempengaruhi perolehan dan ketahanan laba perusahaan.

Hasil ini mendukung teori keagenan dimana manajemen dengan informasi yang dimilikinya berusaha memaksimumkan nilai perusahaan dengan hasil laba perusahaan pada kegiatan operasional perusahaan sebagai kegiatan utama perusahaan. Hal ini akan membuat kepercayaan investor dalam menanam modal pada perusahaan tersebut akan tetap terjaga.

\section{Pengaruh Tingkat Hutang terhadap Persistensi Laba \\ Variabel tingkat hutang} menunjukan koefisien regresi sebesar 0,203172 dengan nilai signifikansi sebesar 0,0312. Karena tingkat signifikansi lebih kecil dari $\alpha=5 \%$ $(0,0342<0,050)$ maka hipotesis pertama $\mathrm{H} 2$ diterima, yang artinya bahwa tingkat hutang berpengaruh positif signifikan terhadap persistensi laba. Hasil penelitian ini sejalan dengan penelitian yang dilakukan oleh Septavita (2016) bahwa tingkat hutang memiliki pengaruh positif 
dan signifikan terhadap persistensi laba. Dan hasil penelitian ini bertolak belakang dengan penelitian yang dilakukan oleh Linawati (2017) dan Sukman (2017) yang menyatakan bahwa tingkat hutang tidak berpengaruh terhadap persistensi laba.

Dilihat dari hasil penelitian perusahaan memiliki pinjaman hutang untuk melakukan pendanaan dalam meningkatkan laba perusahaan. Hal ini berhubungan dengan tingkat solvabilitas keuangan yang dimiliki oleh perusahaan. Besarnya tingkat utang perusahaan akan menyebabkan perusahaan meningkatkan persistensi laba dengan tujuan untuk mempertahankan kinerja yang baik dimata investor dan auditor karena dengan kinerja yang baik diharapkan kreditor tetap memiliki kepercayaan terhadap perusahaan, sehingga akan mudah mengucurkan dana, dan perusahaan akan memperoleh kemudahan dalam proses pembayaran.

Hasil ini mendukung teori keagenan selain manajemen akan memaksimumkan nilai perusahaan, manajemen juga dituntut untuk mengelola kinerja perusahaan dengan baik pula. Terlihat dari keputusan dalam melakukan pinjaman terhadap pihak ketiga dan perusahaan dapat meningkatkan laba perusahaan yang bertahan dari tiaptiap periodenya. Sehingga kondisi ekonomi perusahaan akan tetap stabil dikarenakan perusahaan mampu menutupi hutang dan bunga dengan laba yang diperoleh. Maka para pemegang saham akan tertarik untuk menanamkan modalnya pada perusahaan tersebut. Dikarenakan mampu menjaga stabilitas keuangan ketika melakukan pinjaman dalam rangka mendanai perusahaan.

\section{Pengaruh Ukuran Perusahaan terhadap Persistensi Laba}

Variabel ukuran perusahaan menunjukan koefisien sebesar 0,031130 dengan nilai signifikansi sebesar 0,2913 Karena tingkat signifikansi lebih besar dari $\alpha=5 \%$ $(0,2913>0,050)$ maka hipotesis pertama H3 ditolak, yang artinya bahwa ukuran perusahaan tidak berpengaruh terhadap persistensi laba. Hasil penelitian ini sejalan dengan hasil penelitian yang dilakukan oleh (Linawati, 2017) dan Sukman (2017) yang menyatakan bahwa ukuran perusahaan tidak memiliki pengaruh terhadap persistensi laba Namun hal ini berlawanan dengan penelitian yang dilakukan oleh (Dewi dan Putri, 2015) dan Septavita (2016) yang menyatakan ukuran perusahaan memiliki pengaruh positif dan signifikan terhadap persistensi laba.

Bahwa besar kecilnya aset suatu perusahaan tidak berpengaruh terhadap peningkatan/penurunan laba perusahaan. dikarenakan manajemen akan melakukan kinerja sesuai dengan adaya aset-aset yang dimiliki 
perusahaan. Hal ini mendukung teori Relevansi melihat dari total aset yang dimiliki perusahaan dan nilai laba perusahaan yang diperoleh pada tiap periode. Dapat dijadikan prediksi bagi investor bagaimana perusahaan mengelola aset-asetnya untuk mendapatkan laba disetiap periode, dari hal ini investor dapat mengetahui tingkat profitabilitas perusahaan dalam menggunakan aset-asetnya.

\section{KESIMPULAN}

Kesimpulan yang dapat diambil dalam penelitian ini yang melibatkan Arus Kas Operasi, Tingkat Hutang, dan Ukuran Perusahaan terhadap Persistensi Laba dalah sebagai berikut :

$$
\text { Arus Kas Operasi }
$$

berpengaruh Positif dan Signifikan terhadap Persistensi Laba. Hal tersebut mengartikan bahwa semakin tinggi Arus Kas Operasi, maka hasil produktivitas operasional perusahaan yang semakin baik dan akan memiliki kemampuan dalam mempertahakan laba yang dicapai perusahaan dari periode ke periode berikutnya.

Tingkat Hutang berpengaruh positif Signifikan terhadap Persistensi Laba. Hal tersebut mengartikan bahwa tingkat hutang perusahaan yang semakin tinggi, akan memberikan kekuatan pendanaan perusahaan dalam melakukan investasi dan meningkatkan laba perusahaan agar berkembang dan mempertahankan laba dari tahun ke tahun.

Ukuran Perusahaan tidak berpengaruh terhadap Persistensi Laba. Hal tersebut mengartikan bahwa besar kecilnya ukuran perusahaan tidak mempengaruhi tingkat persistensi laba. Dikarenakan manajer akan berprilaku sesuai kepentingan bersama.

\section{DAFTAR PUSTAKA}

Asma, Tuti Nur. (2013). Pengaruh Aliran Kas Dan Perbedaan Antara Laba Akuntansi Dengan Laba Fiskal Terhadap Persistensi Laba. Publikasi ilmiah. Program Sarjana Fakultas Ekonomi Universitas Negeri Padang. Vol 1, No 1. Hal 116. Retrived http://ejournal.unp.ac.id/stude nts/index.php/akt/article/view 195

Ariyani,.D, Wulandari,. R. (2017). Pengaruh Book Tax Differences Dan Arus Kas Terhadap Persistensi Laba (Studi Empiris Pada Perusahaan Manufaktur Yang Terdaftar Di Bei). Keberlanjutan : Jurnal Manajemen Dan Akuntansi. Vol 2, No 2. Hal 547-563 Retrived http://openjournal.unpam.ac.i d/index.php/keberlanjutan/arti cle/view/929

Dewi, Ni Putu Lestari; Putri, I.G.A.M Asri Dwija. (2015). Pengaruh Book-Tax Difference, Arus Kas Operasi, Arus Kas Akrual, 
Dan Ukuran Perusahaan Pada Persistensi Laba. E-Jurnal Akuntansi, [S.L.], V. 10, N. 1, P. 244-260. ISSN 2302-8556. Retrived https://ojs.unud.ac.id/index.p hp/Akuntansi/article/view/99 74

Hayati, Okta Sabridal. (2014). Pengaruh Volatilitas Arus Kas Dan Tingkat Hutang Terhadap Persistensi Laba (Studi Kasus Pada Perusahaan Manufaktur yang Terdaftar Di Bei Tahun 20092011. Publikasi Ilmiah Program Sarjana (S1) Pada Program Studi Akuntansi Fakultas Ekonomi Universitas Negeri Padang.Vol 2, No 1. Hal 119. Retrived http://ejournal.unp.ac.id/stude nts/index.php/akt/article/view $/ 855$

Nurochman, A., \& Solikhah, B. (2015). Pengaruh Good Corporate Governance, Tingkat Hutang Dan Ukuran Perusahaan Terhadap Persistensi Laba. Accounting Analysis Journal, 4(4). Hal 1 - 9. Retrived : https://journal.unnes.ac.id/sju/ index.php/aaj/article/view/91 11

Linawati. (2017). Pengaruh Tingkat Hutang, Arus Kas Dan Akrual Terhadap Persistensi Laba Dengan Corporate Governance Sebagai Variabel Moderating (Studi Empiris pada Perusahaan yang Terdaftar di BEI Tahun 20112015). Jurnal Universitas Pamulang.Vol 2, No 2. Hal
678 - 703. Retrived : http://openjournal.unpam.ac.i d/index.php/keberlanjutan/arti cle/view/935

Septavita, Nurul. (2016). Pengaruh Book Tax Differences, Arus Kas Operasi, Tingkat Hutang, Dan Ukuran Perusahaan Terhadap Persistensi Laba(Studi Empiris Pada Perusahaan Manufaktur Yang Terdaftar Di Bei Tahun 2011 - 2013). JOM Fekon, Vol.3 No.1. Hal 1309 - 1323. Retrived https://jom.unri.ac.id/index.p hp/JOMFEKON/article/view/ 11484

Sukman. (2017). Pengaruh Arus Kas Operasi, Tingkat Utang, Dan Ukuran Perusahaan Terhadap Persistensi Laba Dengan Book Tax Differences Sebagai Variabel Moderating (Studi Empiris Pada Perusahaan Manufaktur Yang Terdaftar Di Bursa Efek Indonesia). Publikasi Ilmiah. Fakultas Ekonomi dan Bisnis Islam UIN Alauddin Makassar. Hal 1 - 106. Retrived http://repositori.uinalauddin.ac.id/3325/

http://kompasiana.com yang dikutip 02 Mei 2020 